\title{
Malaysian Principals' Technology Leadership Practices and Curriculum Management
}

\author{
Mohd Izham Mohd Hamzah*, Faridah Juraime, Azlin Norhaini Mansor \\ Faculty of Education, The National University of Malaysia, Bangi, Malaysia \\ Email: "izham@ukm.edu.my
}

Received 23 March 2016; accepted 16 May 2016; published 19 May 2016

Copyright (C) 2016 by authors and Scientific Research Publishing Inc.

This work is licensed under the Creative Commons Attribution International License (CC BY). http://creativecommons.org/licenses/by/4.0/

(c) (i) Open Access

\section{Abstract}

School leaders face challenges in using technology to upgrade teaching and learning processes in the twenty-first century as they must also become role models in its usage. Thus technology must be used not only for teaching and learning processes, but also in their organisational management. The aim of this research is first, to identify the level of technology leadership and competency in curriculum activity management among secondary school principals in Malaysia; second, to determine if technology leadership practices and curriculum activity management differ based on school location; third, to analyse if there is a correlation between technology leadership and competency of curriculum activity management. This quantitative style research used questionnaire for data collection involving 341 randomly selected Malaysian principals. Data collected was then analysed using descriptive and inference analysis. Findings show that Malaysian principals practice technology leadership at a very high level, and are also very competent at managing curriculum activity. T-test analysis found that urban principals' technology leadership practices are significantly higher than their rural counterparts, but their curriculum management competencies are at the same level. Findings also show that there is a low yet significant correlation between technology leadership and curriculum management competencies. In light of this information, we recommend further in-depth studies to explore the rural-urban gap technology leadership scenario, thus finding possible solutions in narrowing the academic achieve- ment gap between rural and urban schools.

\section{Keywords}

Technology Leadership, Curriculum Management, Secondary Schools

\footnotetext{
"Corresponding author.
} 


\section{Introduction}

The use of information and communication technology (ICT) in education is not new. In fact, it was introduced in the United States and many European countries in the early 1960s. The transformation of ICT in Malaysian education started in the early 1990s. From that starting point, the Malaysian Ministry of Education (MOE) has initiated multiple initiatives in schools by providing physical and non-physical infrastructure to enable ICT to be used in teaching and learning processes (MOE, 2013).

ICT transformation processes need to be strengthened in many areas, thus relevant upgrades need to be performed to ensure its competitiveness and relevance to the world today. To achieve this, MOE is currently conducting renewal processes through the Malaysian Education Development Plan 2013-2025 (MOE, 2012) and its Seventh Shift, which aims to capitalise on the potential of ICT in enhancing the quality of learning. This focus is important because in the rapidly changing world of today, ICT has the potential to drive learning and teaching processes towards better academic achievement, particularly in schools (MOE, 2012).

The general opinion is that technology has immense potential for enhanced school management, teaching processes and student performance; since the implementation of formal education there has never been any other tool with this level of potential to positively affect student performance and enhance the learning and teaching culture in schools (Brockmeier, Sermon, \& Hope, 2005). Even though standard practices in teaching and learning have changed, the role of computers as a component of teaching and learning has to be maintained. Computers should be maintained as an instructional medium and management tool (Creighton, 2003). Changes and advancement in the education system nowadays assist school management, especially principals, to make decisions in matters pertaining to curriculum management.

To achieve that goal, effective, excellent and knowledgeable school leadership is important in maximising the potential of ICT resources in school management systems and teaching and learning processes. With this leadership being provided to educators, it is hoped that the excellence expected from the education system can and will be achieved.

\section{Literature Review}

Technology leadership is an aspect of the administrator role involving planning and implementing activities related to technology. Administrators need to shift from a technology infrastructure focus to a technology integration focus in order to strengthen the process of teaching and learning and to achieve efficient school management (Flanagan \& Jacobsen, 2003). According to Robertson, Grady, Fluck and Webb (2006), implementing technological changes in organisations such as schools requires administrators such as principals to begin before implementing the changes at a school level. An inability of administrators to identify the effects of technology on education will cause a failure in technology use for management and administrative functions as well as for classroom teaching and learning processes.

This is in line with the current era which requires technology leaders in schools to master ICT effectively and efficiently, especially within administration and management where the survival of an organisation rides on the wave of globalisation. To assist educators in mastering computer skills and knowledge the principal has to transform every aspect of work in accordance with ICT information management in schools. This efficient management and teaching and learning is crucial if education is to remain competitive in this era of globalisation.

Johar (2011) states that effective, knowledgeable and skill-based school leadership is important in determining whether technology use can improve teaching and learning processes. This is because most school leaders are not comfortable being leaders of technology, or are uncertain if leadership in technology can improve and enhance the teaching and learning process. According to Muda (2005), policy changes and innovations by MOE need dynamic and flexible leaders who are aware of their surroundings.

According to research conducted by Hoque, Razak and Zohora (2012), 80\% of schools in Malaysia do not have visions and policies relating to technology and $88 \%$ do not have plans for the integration of ICT. Wang (2010) research shows that there are problems in technology leadership practices, especially among principals, which stem from a lack of vision and commitment rather than from a weakness in resource management or a lack of empowerment in management and administration. The statements and findings detailed above necessitate detailed investigation into principals' leadership practices in integrating technology, especially within management, school administration and teaching and learning processes, so that organisational excellence and en- 
hanced school achievement can be attained.

\section{Malaysian School Principals Competency Standards (MSCPS)}

Competency is defined as the combination of knowledge, skills and personal traits that need to be present in a leader. Competency also comprises a leader's performance and their ability to fulfil their duties and responsibilities in the best possible way. In the context of leadership in schools, school principals are an internal school entity possessing a strategic influence on the creation and realisation of the goals and visions determined by the school. Therefore, principals, as school leaders, have a duty and responsibility to manage and lead complex and challenging schools and to produce quality education and efficient institutions (Institute Aminuddin Baki, 2010). A competent principal will efficiently manage curriculum function, co-curricular activities, organisational aspects and more (Institute Aminuddin Baki, 2010).

A school principal's competency will always be the main focus for enhancing the effectiveness and efficiency of a school. This is because the challenges faced by a school principal nowadays are more complex (Purba, 2009) and the tasks that have to be completed are much heavier (Dharma, 2008; Beatriz, Deborah, \& Hunter, 2008). Therefore, school principals need to be able to efficiently and effectively carry out their role as a school-centralised leader and teacher educator, as well as managing operational aspects which support student success (Interstate School Leadership Licensure Consortium, 2008; Leithwood \& Riehl, 2005; Waters, Marzano, \& McNulty, 2003). In dealing with increasingly complex challenges, school principals are required to possess multiple leadership competencies (Institute Aminuddin Baki, 2006; Interstate School Leadership Licensure Consortium, 2008) and to always strive to improve their competency (Purba, 2009). This is very important because school principal competency is the basis for organisations, such as schools to achieve success.

MSPCS is based on Vision 2020, the National Education Policy and the National Education Philosophy as well as other contemporary education-related theories. This document outlines knowledge, skills, values and best practices and was established through discussion and consultation with various parties including assistant principals, principals and headmasters, officers in the District Education Office, the State Education Department and other departments of the Education Ministry. MSPCS provides competency standards in nine fields: Organisation; Management and Leadership; Curriculum Management; Co-Curricular Management; Student Affairs Management; Financial Management; Office Administration Management; Environmental and Physical Facilities Management; Human Resource Management and Development; and External Communications Management.

In conclusion, curriculum management is the primary duty of the principal and a determining factor in a school's success. Therefore, principals need to have superior skills and knowledge as they are responsible for providing teaching and learning processes which reflect the current technological age. With effective technology leadership, quality teaching and learning processes can be achieved because a principal's skill in curriculum management has a positive relationship with the success and academic achievement of students and the school itself.

\section{Objectives of Research}

This purpose of this research is to achieve the following objectives:

1) To identify the level of technology leadership practices and curriculum management competencies as outlined in the MSPCS among principals of daily secondary schools.

2) To determine differences in technology leadership practices and curriculum management competencies with regards to school location.

3) To determine the relationship between technology leadership and curriculum management among principals of daily secondary schools.

\section{Research Hypotheses}

Ho1 There is no significant difference between the technology leadership and curriculum management competency of principals based in different school locations.

$\mathrm{Hol}_{1}$ There is no significant difference in technology leadership practices of principals based in different school locations. 
$\mathrm{Hol}_{2}$ There is no significant difference in curriculum management competency levels among principals based in different school locations.

Ho2 There is no significant relationship between a principal's technology leadership and curriculum management in schools.

\section{Methodology}

This research employed a survey quantitative research design involving 420 principals selected randomly from 1984 Malaysian daily secondary schools. Questionnaires were mailed to all 420 selected schools, 400 were returned and only 341 qualify for further analysis.

The data needed for this research was collected based on the five dimensions of technology leadership outlined by the National Educational Technology Standard-Administrators (NETS-A, 2009) and the Society for Technology in Education, (ISTE, 2002): visionary leadership; digital age learning culture; excellence in professional practices; systemic improvement; and digital citizenship. Whilst data for curriculum management was self developed based on MSPCS (IAB, 2006), consist of three elements, namely knowledge standard, pro- fessional value standard and best practice standards.

\section{Research Findings}

The findings and discussion for this research refers to analysed data derived using SPSS Version 22. The researcher used descriptive statistics and statistical inference as the main analysis methods, which are appropriate for the questions being asked in this research. According to Moidunny (2009), the utilisation of these two approaches allows for inferences and generalisations to be made.

\subsection{Profile of the Respondents}

This section provides basic information regarding the background and profile of respondents' demographics, including school location. Research respondents were categorised according to school location -157 (46\%) respondents are from the urban school category as opposed to 184 (54\%) from the rural school category (Table 1).

\subsection{Principal's Technology Leadership Practices}

In determining levels of technology leadership among principals, the researcher looked at the whole dimension of technology leadership encompassing: visionary leadership; digital age learning culture; excellence in professional practice; systemic improvement and digital citizenship (NETS-A, 2009). The level of technology leadership practice was determined according to the mean score interpretation method as shown in Table 2. Based on the mean score interpretation, a detailed analysis of technology leadership practices among principals in daily secondary schools is provided in Table 3 .

Table 3 shows that the overall mean score for technology leadership is 4.26 . This clearly shows that the implementation of technology leadership practices by principals is at a very high level. In detail, Table 3 shows that the dimensions of visionary leadership, systemic improvement and digital citizenship are at a very high mean score interpretation, with systemic improvement carrying the highest mean score $(\min =4.42, \mathrm{SP}=$ $0.433)$, followed by visionary leadership $(\mathrm{min}=4.36, \mathrm{SP}=0.423)$ and digital citizenship $(\mathrm{min}=4.25, \mathrm{SP}=$ $0.446)$. The analysis also shows that digital age learning culture $(\min =4.14, \mathrm{SP}=0.432)$ and excellence in professional practice $(\min =4.12, \mathrm{SP}=0.468)$ are at a high mean score interpretation.

\subsection{Principals Curriculum Management Competency Levels}

In determining curriculum management competency levels based on the MSPCS, the researcher looked at dimensions of knowledge standards, professional values standards and best practice standards. Curriculum management competency levels were also determined based on the mean score interpretation in Table 2. Based on the mean score interpretation, an overall detailed analysis on curriculum management competency levels among principals in daily secondary schools is shown in Table 4.

Table 4 shows that the overall mean score for curriculum management competency level among principals is 4.72. This shows that the implementation level for curriculum management competency among principals is 
Table 1. Profile of respondents.

\begin{tabular}{ccc}
\hline Location & Frequency (n) & Percentage (\%) \\
\hline Urban & 157 & 46.0 \\
Rural & 184 & 54.0 \\
\hline
\end{tabular}

Table 2. Mean score interpretation.

\begin{tabular}{cc}
\hline Mean Score & Interpretation \\
\hline $1.00-1.80$ & Very Low \\
$1.81-2.60$ & Low \\
$2.61-3.20$ & Medium \\
$3.21-4.20$ & High \\
$4.21-5.00$ & Very High \\
\hline
\end{tabular}

Source: Moidunny (2009).

Table 3. Levels of technology leadership practices.

\begin{tabular}{cccc}
\hline Variable & Mean & Standard Deviation & Score Interpretation \\
\hline Visionary leadership & 4.36 & 0.423 & Very High \\
Digital age learning culture & 4.14 & 0.432 & High \\
Excellence in professional practice & 4.12 & 0.468 & High \\
Systemic Improvement & 4.42 & 0.433 & Very High \\
Digital Citizenship & 4.25 & 0.446 & Very High \\
Overall & 4.26 & & Very High \\
\hline
\end{tabular}

Table 4. Level of curriculum management competencies.

\begin{tabular}{cccc}
\hline Variable & Mean & SD & Score Interpretation \\
\hline Knowledge Standard & 4.67 & 0.373 & Very High \\
Professional Value Standard & 4.79 & 0.327 & Very High \\
Best Practice Standard & 4.71 & 0.358 & Very High \\
Overall & 4.72 & & Very High \\
\hline
\end{tabular}

very high. In detail, the analysis shows that professional value standards obtained the highest mean score at 4.79 $(\mathrm{SP}=0.327)$ and best practice standards obtained the second highest score at $4.71(\mathrm{SP}=0.358)$. Finally, the mean score for the knowledge standard was $4.67(\mathrm{SP}=0.373)$.

\subsection{Principals Technology Leadership and Curriculum Management Practices Based on Location}

Ho1 $1_{1}$ There is no significant difference between the technology leadership and curriculum management competency of principals in different school locations.

Table 5 shows that there is a significant difference at a t-value $(2.151)$ and $p=0.032(p<0.05)$. Therefore, the null hypothesis $\left(\mathrm{Hol}_{1}\right)$ is rejected. The results show a significant difference in the levels of technology leadership among principals in urban and rural schools.

$\mathrm{Hol}_{2}$ There is no significant difference in curriculum management competency levels among principals based in different school locations. 
Table 6 shows that there are no significant differences, with a t-value $(0.130)$ and $p=0.897(p>0.05)$. Therefore, the null hypothesis $\left(\mathrm{Ho}_{2}\right)$ is accepted. The results show no significant difference in the levels of curriculum management competency between principals in urban and rural schools.

\subsection{Relationship between Technology Leadership and Curriculum Management Competencies}

Ho2 There is no significant relationship between a principal's technology leadership and curriculum management in schools.

To determine the strength of the relationship, the researcher used an estimated strength according to the rating based on Pearson's correlation coefficient $\mathrm{r}(\mathrm{r}=-1$ to +1$)$ by Jackson (2006) as shown in Table 7.

Table 8 shows that the correlation coefficient is at a value of $r=0.483$. This shows that the relationship between technology leadership and curriculum management competencies is at a moderate level. The value $p=$ 0.000 is less than 0.05 . The results of this analysis show that the null hypothesis (Ho2) is rejected. There is a significant moderate correlation between technology leadership and curriculum management competenciesamong principals of daily secondary schools in Malaysia.

Table 5. T-test for technology leadership among principals based on school location.

\begin{tabular}{ccccccc}
\hline Location & $\mathrm{n}$ & Mean & SD & df & t & Sig. \\
Urban & 157 & 4.309 & 0.371 & 339 & 2.151 & 0.032 \\
Rural & 184 & 4.221 & 0.380 & & & \\
\hline$p<0.05$. & & & &
\end{tabular}

Table 6. T-test for curriculum management competency among principals based on location.

\begin{tabular}{ccccccc}
\hline Location & $\mathrm{n}$ & Mean & $\mathrm{SD}$ & $\mathrm{df}$ & $\mathrm{t}$ & Sig. \\
\hline Urban & 157 & 4.723 & 0.323 & 339 & 0.130 & 0.897 \\
Rural & 184 & 4.719 & 0.320 & & & \\
\hline
\end{tabular}

$p<0.05$.

Table 7. Degree of correlation between two variables.

\begin{tabular}{|c|c|}
\hline Correlation coefficient & Degree of correlation \\
\hline $\pm 0.70-1.00$ & High \\
\hline $\pm 0.30-0.69$ & Medium \\
\hline $\pm 0.00-0.29$ & Low/Weak \\
\hline
\end{tabular}

Source: Jackson (2006).

Table 8. Correlation between technology leadership and curriculum management competencies.

\begin{tabular}{cccc}
\hline & & Technology Leadership & Curriculum Management \\
\hline & Pearson's Correlation & 1 & $0.483^{* *}$ \\
Technology Leadership & Sig. (2-tailed) & 341 & 0.000 \\
N & Pearson's Correlation & $0.483^{* *}$ & 341 \\
Curriculum Management & Sig. (2-tailed) & 0.000 & 341 \\
\hline
\end{tabular}

${ }^{* *}$ Correlation is significant at the 0.01 level (2-tailed). 


\section{Discussion}

This study found that the level of technology leadership among principals is practiced at a very high level. Specifically, with the highest mean value of 4.42 , technology leadership practices among principals of daily secondary schools focus on systemic improvement as compared to other dimensions. This finding is in line with the statement that administrators play an important role as technology leaders (Anderson \& Dexter, 2005; Dikkers, Hughes, \& McLeod, 2005; Fletcher, 2009; Gerard, Bowyer, \& Linn, 2008; ISTE, 2007; McLeod, 2008; Slenning, 2000). Every effort towards technology use in schools will be in jeopardy unless school administrators become active technology leaders in schools (Anderson \& Dexter, 2005).

This research also found that curriculum management competency levels among principals are at a very high level. In line with this finding, Waters et al. (2003), Leithwood \& Riehl (2005) and the Interstate School Leadership Licensure Consortium (2008) state that school principals need competency to fulfil their leadership duties (school-focused, educator learning and operational aspects) in order to support the success of students in an efficient and effective manner. School principals are required to have competencies in various aspects of leadership (Institute Aminuddin Baki, 2013; Interstate School Leadership Licensure Consortium, 2008) and to always strive for improved effort and competency in mastery adaptation (Purba, 2009). This is important as school principals' competency is the basis for organisational success.

These research findings also show a significant difference in technology leadership practices based on school location whereas there is no significant difference in curriculum management competency based on school location. This finding is in line with the research of Chen (2004); Murphy, Elliots, Goldring, \& Porter (2006); Mansor (2006); Hallinger (2008); Kadir (2008); Alias (2009); Inspectorate and Quality Assurance (2010) and Imam (2012) who found that demographics such as school type and location are the main factors affecting the practices and leadership style of principals.

In order to overcome the difference in these technology leadership practices, MOE, through a cooperation with the Ministry of Waterworks and Communications, has enabled schools to access broadband internet and has also weaved infrastructure and ICT hardware through local networks and wireless technology. MOE's challenge continues in the Ninth Malaysia Plan as they work to ensure that infrastructure, hardware, software and adequate training are continually provided to rural schools identified as being less exposed to ICT technology facilities. With this initiative in place, all schools in rural areas will be equipped with computer labs and adequate hardware and software.

Finally, this research was conducted to identify whether there is a correlation between technology leadership and curriculum management of principals in daily secondary schools. The findings show that there is a moderate significant correlation between technology leadership and curriculum management among principals. These findings clearly indicate that technology leadership, and the use of technology in teaching and learning can improve schools' academic performance. Thus implying that within the Malaysian context, achievement gap between rural and urban schools can be narrowed through technology leadership.

Further, this supports Chen's (2004) findings that for the last few decades ICT technology facilities in education has been a determining factor of education and that to succeed in implementing technology in education principals need to change current leadership practices. On the aspect of curriculum management, Metcalf (2012) states that twenty-first century school leaders face a challenging task in applying technology to improve teaching and learning processes and must become role models to encourage the use of technology in teaching and learning as well as in organisational management. As such, Robinson, Lloyd and Rowe (2008) state that the effects of technology leadership on students' learning are three to four times greater than transformational leadership.

In conclusion, these findings highlight implications for management and administration in schools, namely from the standpoint of technological leadership among school administrators, particularly principals. In an effort to encourage a culture of technologically driven management, school principals need to work with everyone in the school to create a shared vision for comprehensive technology integration. In addition, as technology leaders in schools, administrators have to develop a supportive organisational structure for technology use, especially in structuring the utilisation of technology in teaching and learning processes and organisational management.

\section{Conclusion}

This research clearly shows that the role of information technology is crucial in the ever-challenging education system. School administrators, particularly principals, do not have a choice in accepting the technological cli- 
mate of the present day. A world which is now considered borderless in terms of information exchange means that schools will unquestioningly accept the application and implementation of ICT. In addition, technology infrastructure provided by MOE will be considered wasteful if not used optimally. The ability and determination of the government in providing these facilities should be commended thus should be used to its full potential.

Administrators and educators, especially in the rural areas, need to integrate ICT at every aspect in school management focusing on the teaching and learning process. Technology management also need focus on improved performance management efficiency by obtaining and using correct information in a timely manner. To achieve this, the role of technology leaders should always be improved to enable better integration in management and administration processes, and also in the teaching and learning process. The fact is that ICT can increase communication capabilities in an organisation and create an environment of friendly competition among school citizens. Therefore, the expansion of ICT technology needs to be explored further so that the visions and missions of school management can be achieved and enhanced.

\section{References}

Alias, B. S. (2009). Analysis of Competencies Based on Personal Qualities, Knowledge, Skills, and Practices in Various Areas of Management among the Principals in Malaysia. Unpublished Doctoral Dissertation, Bangi: National University of Malaysia.

Anderson, R. E., \& Dexter, S. (2005). School Technology Leadership: An Empirical Investigation of Prevalence and Effect. Educational Administration Quarterly Journal, 40, 49-82. http://dx.doi.org/10.1177/0013161X04269517

Beatriz, P., Deborah, N., \& Hunter, M. (2008). Improving School Leadership Activity (Vol. 1). OECD: Policy and Practice.

Best, J. W., \& Kahn, J. V. (2006). Research in Education (10th ed.). Boston: Pearson Education, Inc.

Brockmeier, L. L., Sermon, J. M., \& Hope, W. C. (2005). Principals' Relationship with Computer Technology. National Association of Secondary School Principals Bulletin, 89, 45-63. http://dx.doi.org/10.1177/019263650508964305

Cavana, R., Delahaye, B., \& Sekaran, U. (2001). Applied Business Research: Qualitative and Quantitative Methods (3rd ed.). Australia: John Wiley \& Sons.

Chen, L. L. (2004). Pedagogical Strategies to Increase Pre-Service Teachers' Confidence in Computer Learning. Educational Technology \& Society, 7, 50-60.

Chua, Y. P. (2006). Methods and Statistics Research: Book 1 Research Methods. Kuala Lumpur: McGraw Hill.

Creighton, T. (2003). The Principal as Technology Leader. Thousand Oaks, CA: Corwin Press, Inc.

Dharma, S. (2008). The School Principal Is Incompetent in Indonesia. Retrieved from Harian Kompas.com.,11 Ogos 2008.

Dikkers, A. G., Hughes, J. E., \& McLeod, S. (2005). A Bridge to Success. School Technology Leadership Initiative. T.H.E. Journal, 32, 20-24.

Flanagan, L., \& Jacobsen, M. (2003). Technology Leadership for Twenty-First Century Principal. Journal of Educational Administration, 41, 124-142. http://dx.doi.org/10.1108/09578230310464648

Fletcher, G. H. (2009). A Matter of Principals. T.H.E. Journal, 36, 22-28.

Gay, L. R., \& Airasian, P. (2003). Educational Research: Competencies for Analysis and Application (7th ed.). Columbus, OH: Merrill Prentice Hall.

Gerard, L. F., Bowyer, J. B., \& Linn, M. C. (2008). Principal Leadership for Technology-Enhanced Learning in Science. Journal of Science Education and Technology, 17, 1-18. http://dx.doi.org/10.1007/s10956-007-9070-6

Hallinger, P. (2008). Methodologies for Studying School Leadership: A Review of 25 Years of Research Using the Principal Instructional Management Rating Scale. Annual Meeting of the American Educational Research Association, New York, 24-28 March 2008, Version 4.7.

Hoque, K. E., Razak, A. Z. A., \& Zohora, M. F. (2012). ICT Utilization among School Teachers and Principals in Malaysia. International Journal of Academic Research in Progressive Education and Development, 1, 17-34.

Imam, S. S. J. S. (2012). Professional Training and Its Relationship to Treat Personality, Management Skills and Leadership among Principals Novice in Malaysia. Unpublished Doctoral Dissertation, Bangi: The National University of Malaysia.

Inspectorate and Quality Assurance (2010). Malaysia Education Quality Standard 2010. Putrajaya: Ministry of Education. Institute Aminuddin Baki (2006). Malaysian School Principals' Competency Standards (MSCPS). Putrajaya: MOE.

Institute Aminuddin Baki (2010). IAB Moving forward. Putrajaya: MOE.

Institute Aminuddin Baki (2013). ICT Competence of Principal. Putrajaya: MOE.

Interstate School Leadership Licensure Consortium (2008). Educational Leadership Policy Standards. Washington DC: The 
National Policy Board for Educational Administration.

ISTE (2002). National Educational Technology Standards for Administrators. http://cnets.iste.org/administrators/

ISTE (2007). Educational Technology Standard and Performance Indicators for Administrators.

NETS-A (2009). NETS for Administrators 2009. http://www.iste.org/standards/iste-standards/standards-for-administrators

Jackson, S. L. (2006). Research Methods and Statistic: A Critical Thinking Approach (2nd ed.). Belmont, CA: Thomson and Wadsworth.

Johar, M. (2011). Technology Leadership and ICT Competence of Teachers in Islamic Schools in Kuching Sarawak. Thesis Principalship, Washington DC: Institute of Educational Leadership.

Kadir, M. B. A. (2008). Effects of the Leadership and Integrity of Total Quality Management, Human Dimension of Climate Processes in the Organization MARA Institute of Higher Education. Unpublished Doctoral Dissertation, Bangi: The National University of Malaysia.

Leithwood, K. A., \& Riehl, C. (2005). What We Know about Successful School Leadership. Philadelphia, PA: Laboratory for student success, Temple University.

Malaysian Ministry of Education (2013). Malaysia Education Blueprint 2013-2025. Putrajaya: MOE.

Mansor, A. N. (2006). Management Practices Secondary School Principals: A Case Study. Unpublished Doctoral Dissertation, Bangi: The National University of Malaysia.

McLeod, S. (2008). Educational Technology Leadership. Technology \& Learning, 28, 1-4.

Metcalf, W. M. (2012). K-12 Principals' Perceptions of Their Technology Leadership Preparedness. Unpublished Doctoral Dissertation, Statesboro, GA: Georgia Southern University.

Ministry of Education Malaysia (2012). Malaysian Education Blueprint 2013-2025. Putrajaya: MOE.

Moidunny, K. (2009). The Effectiveness of the National Professional Qualification for Educational Leaders (NPQEL). Unpublished Doctoral Dissertation, Bangi: The National University of Malaysia.

Muda, M. (2005). Situational Leadership among School Principals in Malaysia. Unpublished Doctoral Dissertation, Bangi: The National University of Malaysia.

Murphy, J., Elliott, S. N., Goldring, E., \& Porter, A. C. (2006). Learning-Centered Leadership: A Conceptual Foundation. Nashville, TN: Learning Sciences Institute, Vanderbilt University (NJ1).

Purba, S. (2009). Increased Competence through Mentoring in Creating the Professionalism of the Head Rest Is. GenerasiKampus Jurnal, 2, 1-16.

Robertson, M., Grady, N. B., Fluck, A., \& Webb, I. L. (2006). Conversations toward Effective Implementation of Information Communication Technologies in Australian Schools. Journal of Educational Administration, 44, 71-85. http://dx.doi.org/10.1108/09578230610642665

Robinson, V. M. J., Lloyd, C. A., \& Rowe, K. J. (2008). The Impact of Leadership on Student Outcomes: An Analysis of the Differential Effects of Leadership Types. Educational Administration Quarterly, 44, 635-674. http://dx.doi.org/10.1177/0013161X08321509

Slenning, K. (2000). The Future School Manager: Information and Communication Technology Aspects. Educational Media International, 37, 243-249. http://dx.doi.org/10.1080/09523980050210439

Wang, C. H. (2010). Technology Leadership among School Principals: A Technology-Coordinator's Perspective. Journal Asian Social Science, 6, 51-54.

Waters, T., Marzano, R. J., \& McNulty, B. (2003). Balanced Leadership: What 30 Years of Research Tell Us about the Effect of Leadership on Students Achievement. A Working Paper Mid-Continent Research for Education and Learning. Educational Resources Information Center (ERIC). 